\title{
Reproductive Behavior of the Mangrove Crab Ucides cordatus (Crustacea; Brachyura; Ucididae)
}

\author{
Jussiara Candeira Spíndola Linhares ${ }^{*}$ and José Roberto Feitosa Silva \\ ${ }^{I}$ Departamento de Biologia; Centro de Ciências, Universidade de Federal do Ceará; C. P.: 6021; 60440-970; \\ Fortaleza - CE - Brasil
}

\begin{abstract}
The aim of the present work was to study the reproductive behavior of the mangrove crab (Ucides cordatus) in the estuary of the Igaraçú River (Piauí, Brazil). Courtship and mating were observed in December 2007 and in January-March 2009. The most frequently observed reproductive behavior was the transference of eggs onto the abdomen of the female. Some disputes between males and some copulations were observed. The males mated with more than one female each night and all mating activity occurred at night. The establishment of a closed season coinciding with the mating season represented an effective strategy for the preservation of the species when the socioeconomic situation of the community of gatherers was taken into account.
\end{abstract}

Key words: Courtship, Mating, Maturation, Estuary, “Andada”, Seasonality

\section{INTRODUCTION}

Life history theory explains the species diversity and variety in life styles as a result of natural selection, fitness, constraint and adaptation (Stearns 1992). As one of the most important events in the life of the individual, reproduction is closely tied up with the life history theory. Life history strategies reflect the allocation of an organism's resources to the purposes of growth, maintenance and reproduction (Varpe 2006).

In a study on the life history strategies of crabs, Hartnoll and Gould (1988) observed a considerable diversity of reproductive patterns, possibly related to environmental factors. The mating of the crabs depends on the individual level of sexual maturity and stage in the moulting cycle (Hartnoll 1969). In order to mate, the males must have sexually mature gonads, while females can mate before the gonads are fully mature as ovulation generally occurs with some delay (Hartnoll 1969; Sastry 1983; Sainte-Marie 2007).

The stage in the moulting cycle of the female is an important determining factor in reproductive behavior. The mating occurs with the female gonopore decalcified (Adiyodi 1985). In the females of species with calcifying gonopores, mating must take place while the gonopores are flexible, as in the short period between the moulting and complete recalcification of the exoskeleton. However, in many species, mating takes place at a time in the intermoult period when the gonopores become partly decalcified (Hartnoll 1969). Depending on the species, mating is possible with the female undergoing moulting or in the intermoult period, but the carapace of the male must be fully calcified to accomplish the reproduction (Hartnoll 1969).

The time from mating/sperm transference to ovulation/oviposition varies greatly among crab species, but fertilization, ovulation and oviposition

*Author for correspondence: jussiaralinhares@yahoo.com.br 
occur within a relatively short time frame (Hartnoll 1969; Sastry 1983; Diele 2000). Differences may be associated with the moulting stage of the female, the sperm transference and storage method, and the form of fertilization and incubation. The interplay between these aspects and the animal's habitat and lifestyle play an important role in the reproductive success of each species (Sastry 1983).

The mangrove crab, Ucides cordatus (Linnaeus, 1763) may be found in burrows on tidal mangrove mud flats near the sea. By their extensive burrowing and displacement of debris, mangrove crabs contribute to loosening and aerating the soil (Rodrigues et al. 2000), and is key species in nutrient cycling (Wolff et al. 2000; Shories et al. 2003; Nordhaus et al. 2006). The species is distributed throughout the tropical Western Atlantic, from Florida to the Mexican Gulf, Central America, the Antilles, Northern South America and Brazil (Melo 1996). Its large size and savory flesh makes it a popular food and an important fishing resource and source of income for the communities residing in the vicinity of estuaries (Ivo and Gesteira 1999; Rodrigues et al. 2000; Alves and Nishida 2003; 2004; Legat et al. 2005; Diele and Koch 2010).

Despite the socioeconomic importance, the ecology of crabs semi-terrestrial is scarce and this hampers the development of management strategies (Diele et al. 2005). Thus, over the past few years, the population of $U$. cordatus in Northeastern Brazil has declined dramatically, mostly due to habitat destruction, overfishing and disease (Alves et al. 2005; Legat et al. 2005; Boeger et al. 2007). In addition, prior to the establishment of the closed season (IBAMA $34 / 03-N$ of July 24,2003 ), catches of $U$. cordatus actually increased during the mating season (Nordi 1994a; Alves and Nishida 2004) since mating and spawning require the animals to spend more time outside their burrows. (Nordi 1994a; Alves and Nishida 2004; Linhares et al. 2008). The life cycle and daily activity of the mangrove crab has been shown to be directly affected by the tides and the lunar cycle (Alves and Nishida 2002). Thus, according to several studies and crab fishermen interviewed by Souto (2007), the lunar cycle exerted a direct influence on the behavior of the mangrove crab during the mating season.

The objective of the present study was to describe the reproductive behavior of the mangrove crab (Ucides cordatus) during the mating season as a subsidy to public policies protecting the species from overfishing and stock decline.

\section{MATERIALS AND METHODS}

Mangrove crab populations were observed during the mating season in December 2007 and in January-March 2009. The area of study was a mangrove swamp in the estuary of the Igaraçú River, Piauí, Northeastern Brazil (02 ${ }^{\circ} 53^{\prime} \mathrm{S}$ and $41^{\circ}$ 41'W).

The behavior of the crabs was observed and registered on the days when the crabs were engaged in mating activity. During the first hour of observation, the specimens were captured in order to register the gender, shell hardness, carapace width, the presence of eggs, and substratum (mud or roots). The sampled specimens were returned unscathed to the environment. Subsequently, courting and mating behaviors were observed and registered in detail for both the genders. Finally, five specimens of each gender and three mating couples were collected for the laboratory analysis of the gonads according to the methodology of Linhares (2010).

\section{RESULTS}

In the daytime of mating season, the mangrove crabs moved about on the mud flats cautiously in much the same way they did outside the mating season. During the low tide at night, however, mud flats, burrow entrances and red mangrove roots (Rhizophora mangle) were teeming with mating crabs (Fig. 1).

The specimens captured for the measurement included $51.5 \%$ males, $35.1 \%$ egg-bearing females and $13.4 \%$ non-egg-bearing females of a total of 171 crabs. On the average, the carapace width was $69.8 \pm 6.7 \mathrm{~mm}$ (range: 49.95-79) for the males, and $59.8 \pm 6.9 \mathrm{~mm}$ (range: 44.5-74.25) for the females. All the sampled specimens had hard shells. With regard to substratum, the animals occupied mud flats $(60.8 \%)$ and red mangrove roots $(39.2 \%)$, however, with a gender-specific difference. The vast majority of the males (96.6\%) were collected on the mud flats, while the females were predominantly $(77.12 \%)$ observed on the roots. Most of the females perching on the roots $(79.7 \%)$ were egg-bearing. 
An average of 1.5 copulations were observed (range: 0-4) per night. Courtship was initiated as the male positioned himself in the front of the female. In some cases, the female refused the male and withdrew. However, when the female was receptive, the male extended the chelipeds and the second pair of pereopods laterally forming an arch around the female while intermittently opening and closing the abdomen. Standing on the third, fourth and fifth pair of pereopods, the male then drew the female closer until she was firmly secured. With the body raised, the male introduced the gonopod into the female gonopore (Fig. 2). Courtship and mating lasted 15-30 min. Following copulation, the male released the female from his grip. In some cases, the male immediately went in search of another female for mating. During the courtship and mating, the male secreted a foamy substance from the oral cavity.

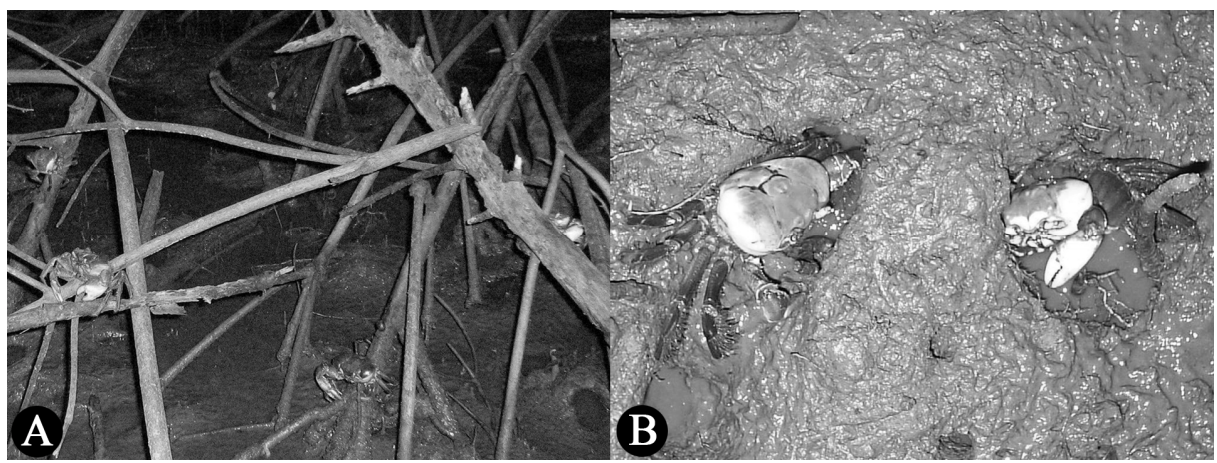

Figure 1- Mangrove crabs (U. cordatus) during mating season. A: females mangrove crabs perching on red mangrove roots; $\mathrm{B}$ : males at the burrow entrance.

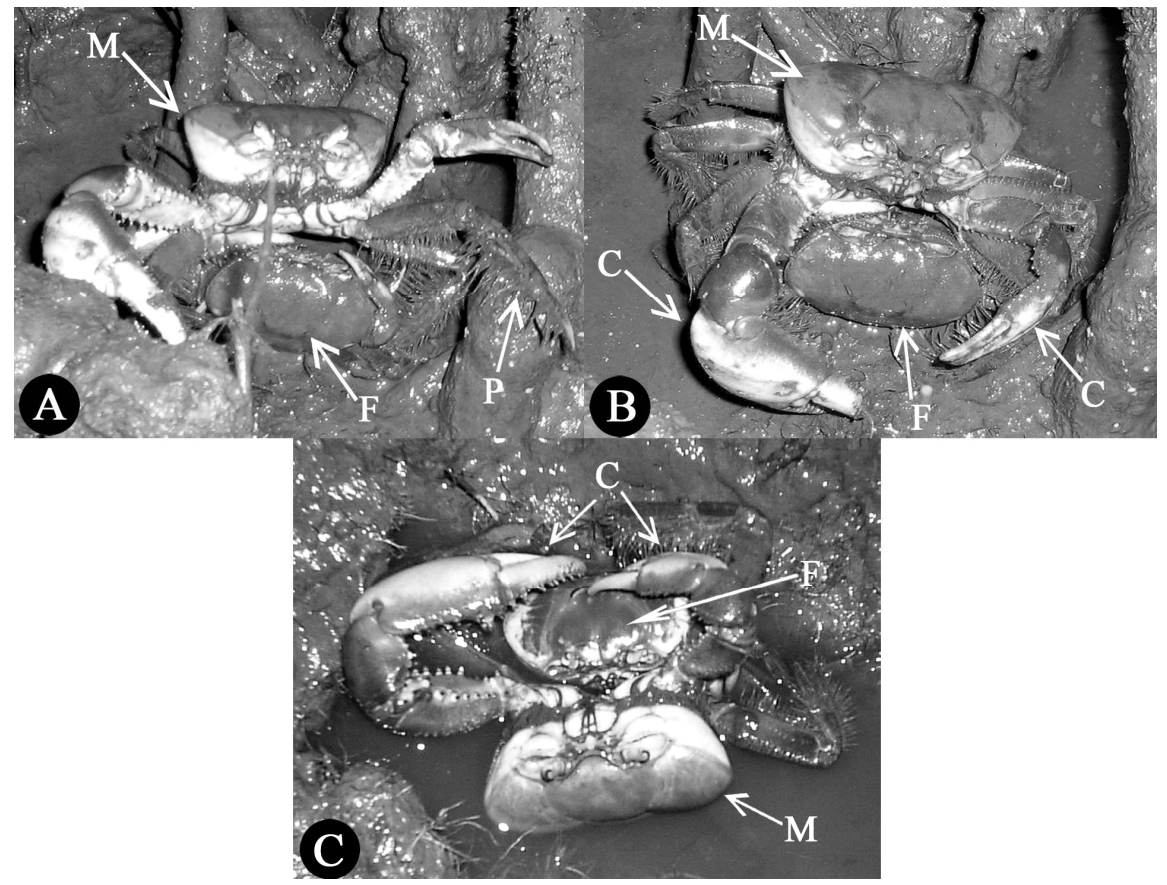

Figure 2 - Courtship and mating of the mangrove crab (U. cordatus). A: male extending chelipeds and second pair of pereopods laterally; B: male using chelipeds and second pair of pereopods to form arch around female; $\mathrm{C}$ : male drawing female closer and securing her firmly. ( $\mathrm{M}=$ male; $\mathrm{F}=$ female $; \mathrm{C}=$ cheliped $\mathrm{P}=$ pereopods $)$. 
Few disputes between the males were observed. When disputing, the males used their claws to prod each other on the carapace or claws. In some cases, a female was seen beside two disputing males.

The most frequently observed reproductive behavior was the transference of eggs onto the abdomen, mostly while the females were perching on the roots. At this point, the egg mass had a liquid appearance (Fig. 3). One female was observed releasing the eggs while on the ground but the egg mass did not come into contact with the substratum.

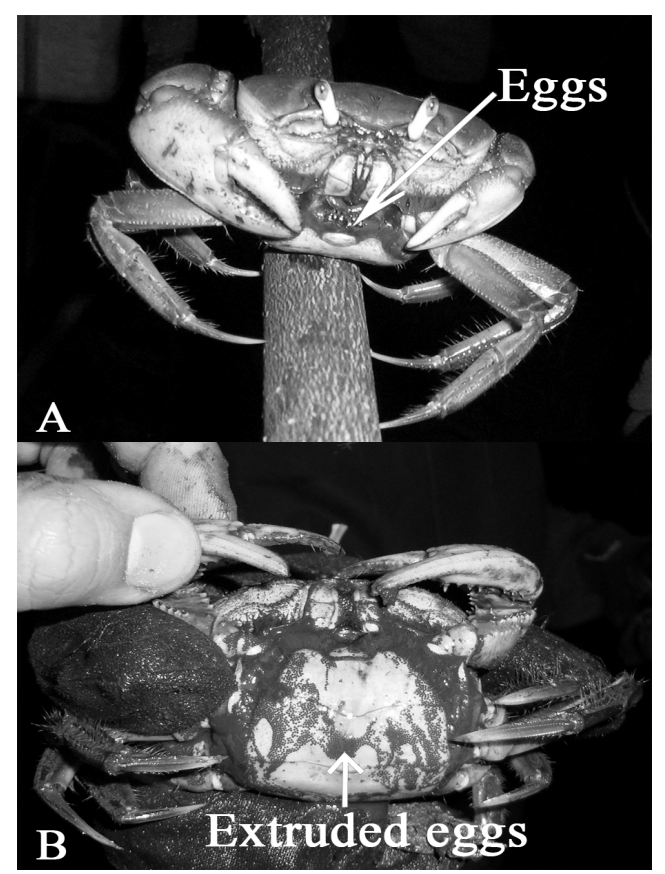

Figure 3 - A: Ovipositing mangrove crab (U. cordatus) on red mangrove roots. B: Egg mass of liquid appearance immediately after oviposition.

Eighty-five percent of the egg-bearing females preferred roots to mud flats. The eggs of these females had a generally liquid appearance, while the eggs of the females observed on mud flats presented a more solid consistency, with the exception of the females still engaged in oviposition.
Mating generally occurred during three consecutive days each month of the mating season. The second day was always the most hectic. Table 1 showed the dates on which mating was observed throughout the study period. The days with the highest level of activity are highlighted.

Table 1 - Mating days of the mangrove crab throughout the study period. The days with the highest level of activity are highlighted.

\begin{tabular}{cc}
\hline Month/year & Mating days of the mangrove crab \\
\hline Dec/07 & $26, \underline{27}$ and 28 \\
$\mathrm{Jan} / 09$ & $13, \underline{14}$ and 15 \\
$\mathrm{Feb} / 09$ & $11, \underline{12}$ and 13 \\
Mar/09 & 12 and $\underline{13}$ \\
\hline
\end{tabular}

On the second mating day in March an interesting phenomenon was observed. During the first 45 minutes of observation, only seven crabs were seen, in contrast with the capture of approximately
40 specimens during the first hour on most other days. This was followed by a heavy rainfall and the sudden appearance of a large number of crabs moving about on the mud flats and roots (roots 
were preferred by the females). Thus, in spite of the small number of crabs captured for the measurement on this occasion, the day was considered the most hectic in terms of mating activity.

The analysis of gonads revealed that all the sampled females were sexually mature and/or in the recovery phase. Non-egg-bearing females presented mature ovaries. In egg-bearing females, the ovaries were in the recovery phase. All the sampled males had spermatophores in the posterior vas deferens, indicating sexual maturity. Thus, all the animals observed in the activity were capable of reproducing.

\section{DISCUSSION}

Crustaceans are considered a dominant and successful group of animals represented by a large number of species with an ample variety of life styles and habitats (Sastry 1983). This diversity is the result of life history patterns and reproductive strategies shaped by a combination of biotic and abiotic factors in each environment (Sastry 1983), as observed in the case of $U$. cordatus.

The males of the mangrove crab grew larger than the females (Alves and Nishida 2004; Diele and Koch 2010). This was too observed for other species of Brachyura, as Chaceon affinis (Pinho et al. 2001), Portunus pelagicus (Xiao and Kuma 2004), Uca inversa (Litulo 2005a), Uca annulipes (Litulo 2005b), Chaceon notialis (Sant'Ana and Pezzuto 2009) and Johngarthia lagostoma (Hartnoll et al. 2009). This was likely related to an aspect of the life history of the female, namely the decrease in the growth rate following the first reproduction (Charniaux-Cotton et al. 1992), which occurred naturally as the functions of growth and reproduction began to compete for the allocation of energy (Hartnoll 1985; Hartnoll and Gould 1988). Thus, the larger size of the males observed in this study could be explained by the fact that all the females were sexually mature, as shown by the laboratory analysis. In other words, mature females tended to be smaller than the males because the development of reproductive tissues required more energy on the part of the females while less energy was made available for the continued body growth. This was also supported by the greater development of the female gonads.
The behavior of the female crustaceans at the time of courtship and mating depends on the stage in the individual moulting cycle. In the species mating during the moulting of the female, courtship is long and elaborate (Adiyodi 1985). It begins in the pre-moulting period and lasts until the new shell of the female has hardened. In the species mating during the intermoult period of the female, courtship is shorter and less elaborate. The species $U$. cordatus mates while both the male and female are in the intermoult period. The courtship is short, behaviors tend to be repetitive and the males are more active than females. In the mating occurring with rigid carapace females, the males crabs abandon the female immediately after copulation, (Hartnoll 1969; Sastry 1983). This pattern was also observed in the present study.

The strategy of mating primarily at night appeared to minimize the risk of attack from the predators during the reproductive activities, such as oviposition.

In a study on the mangrove crab, Costa (1979) found that mating began with the female entering an abandoned burrow from which she was subsequently dragged out by the male. The courtship then began as the male and female prod each other with their claws in preparation for the copulation. This behavior was not observed in the present work, rather the male approached the female frontally with slow movements of the claws.

Earlier studies suggested that the male crabs were successful at mating only if they could physically subdue the female. This was in part a result of the belief that only moulting females copulated. However, it is now known that in many crustacean species, mating occurs while the female is in the intermoult period and therefore requires recognition on part of the male and cooperation on part of the female to be successful (Hartnoll 1969). Silva et al. (1994) reported that the differences in post-maturity development of the second and third pair of pereopods in the spiny lobster (Panulirus laevicauda) could be explained by the need of the male to maneuver the female during the copulation. In the present study, the male crabs used the second pair of pereopods to encircle the female. Thus, in addition to being an organ of locomotion, the second pair of pereopods could be considered a mating-related structure.

Some authors have observed the secretion of a foamy substance from the mouth of the male mangrove crab during the courtship and mating 
(Nascimento 1993; Pinheiro and Fiscarelli 2001). According to some authors, the substance could partly cover the animal. In the present study, however, the substance was secreted in small amounts limited to the oral cavity. Sexual pheromones have already been described for the male and female crustaceans (Bouchard et al. 1996). Thus, it could be hypothesized that the foamy substance observed in the present study contains a pheromone facilitating the approach of the males and females.

It is often difficult to observe crustaceans mating under natural circumstances. There are nevertheless indications that certain species are polygamous (Sastry 1983). In the present study, the mangrove crab clearly displayed polygamous behavior, with the males attempting to mate with more than one female on the same night. The most frequently observed reproductive behavior - the transference of eggs onto the abdomen - was not described earlier. The behavior was almost always observed while the females were perching on the roots. The females transferring the eggs while on the ground avoided contact between the egg mass and the substratum. Due to the liquid consistency of the egg mass upon oviposition and consequent vulnerability to contact with water, females have adopted the strategy of releasing their eggs while perching on dry roots.

As shown by the present study, mangrove crabs in the estuary of the Igaraçú River generally mated during three consecutive days in each month of the mating season. In comparison, Diele (2000) reported 1-4 days of monthly mating activity in a study carried out in the estuary of the Caete River (Pará-BR) and Costa (1979) reported 2-3 days for the crabs in the mangrove swamp of the Ceará River (Ceará-BR). Table 2 reveals a tendency for longer mating seasons with lower latitudes.

Table 2- Mating season of the mangrove crab (U. cordatus) at different latitudes.

\begin{tabular}{|c|c|c|c|c|c|c|c|c|c|c|c|c|c|}
\hline \multirow{2}{*}{ Latitude } & \multirow{2}{*}{ Authors/Year } & \multicolumn{12}{|c|}{ Month } \\
\hline & & $\mathbf{J}$ & $\mathbf{F}$ & $\mathbf{M}$ & $\mathbf{A}$ & $\mathbf{M}$ & $\mathbf{J}$ & $\mathbf{J}$ & $\mathbf{A}$ & $\mathbf{S}$ & $\mathbf{O}$ & $\mathbf{N}$ & D \\
\hline $26^{\circ} 11^{\prime} \mathrm{S}$ & Wunderlich et al. (2008) & $\mathrm{X}$ & & & & & & & & & & & $\mathrm{X}$ \\
\hline $24^{\circ} 41^{\prime} \mathrm{S}$ & Pinheiro and Fiscarelli (2001) & $\mathrm{X}$ & & & & & & & & & & & $\mathrm{X}$ \\
\hline $14^{\circ} 30^{\prime}-15^{\circ} 00^{\prime} \mathrm{S}$ & Vasconcelos (2008)* & $\mathrm{X}$ & $\mathrm{X}$ & $\mathrm{X}$ & & & & & & & & & \\
\hline $12^{\circ} 39^{\prime} \mathrm{S}$ & Souto $(2007) *$ & $\mathrm{X}$ & $\mathrm{X}$ & $\mathrm{X}$ & & & & & & & & & \\
\hline $6^{\circ} 44^{\prime}-6^{\circ} 50^{\prime} \mathrm{S}$ & Alves and Nishida (2004) & $\mathrm{X}$ & $\mathrm{X}$ & $\mathrm{X}$ & & & & & & & & & \\
\hline $3^{\circ} 40^{\prime}-3^{\circ} 45^{\prime} \mathrm{S}$ & Costa/1979 & $\mathrm{X}$ & $\mathrm{X}$ & $\mathrm{X}$ & $\mathrm{X}$ & $\mathrm{X}$ & & & & & & & $\mathrm{X}$ \\
\hline $2^{\circ} 53^{\prime} \mathrm{S}$ & Present study & $\mathrm{X}$ & $\mathrm{X}$ & $\mathrm{X}$ & & & & & & & & & $\mathrm{X}$ \\
\hline $2^{\circ} 43^{\prime}-2^{\circ} 59^{\prime} S$ & Linhares et al. (2008)* & $\mathrm{X}$ & $\mathrm{X}$ & $\mathrm{X}$ & & & & & & & & & $\mathrm{X}$ \\
\hline $1^{\circ} 00^{\prime} \mathrm{S}$ & Diele (2000) & $\mathrm{X}$ & $\mathrm{X}$ & $\mathrm{X}$ & $\mathrm{X}$ & & & & & & & & $\mathrm{X}$ \\
\hline
\end{tabular}

* Period mentioned for the mating station by gatherers.

The reproductively active females swarm in search of a location to release the larvae in the Curimatau River (Rio Grande do Norte-BR), especially by the end of the mating season in March (Vasconcelos et al. 1999). This was not observed in the present study. Morgan (1996) found that the larvae of crab species living near the water's edge could be released inside the burrows in the mud, while the females of species less dependent on the aquatic environment might need to migrate farther. These differences in the reproductive timing and environment could be determined genetically or imposed phenotypically by the environmental conditions (Morgan 1996). The mating season of the mangrove crab is closely tied up with the rainy season. In fact, heavy rainfalls appear to trigger the mating behaviors (Nascimento 1993), perhaps as abrupt changes in the salinity in the animals' burrows stimulates the production of sexual hormones.

Based on the literature (Diele 2000; Pinheiro and Fiscarelli 2001) and the present observations, the lunar phases played an important role in the mating cycle of the mangrove crab. All the mating took place at full moon or new moon. In December 2007, the most hectic mating day coincided with the new moon. In each month of 2009 covered by the study, the reproductive activity started on the third day after full moon. In a study from Pará (Diele 2000), each month reproductive activity was observed to start 1-2 days after the new moon. Wunderlich et al. (2008) found mating activity to be clearly associated with the new moon or full moon, beginning 2-3 days after these events. The observed reproductive behaviors matched the findings from several other 
studies on the crabs, reinforcing the monophyly of the taxon Reptantia (Christtofersen 1988).

Catching mangrove crabs is back-breaking and illpaid work (Nordi 1994a; b; 1995; Alves and Nishida 2003; Linhares et al. 2008; Nordi et al. 2009), but many gatherers have no other significant source of income (Linhares et al. 2008). In addition, a considerable part of the local community obtain an important income from the processing, transportation and sales of $U$. cordatus (Glaser 2003). These facts explained why even though most gatherers realized the establishment of a closed season was an important step towards preserving the mangrove crab stocks Linhares et al. (2008), not all were able to comply with the regulations.

Thus, to develop the effective crab stock management strategies, the policy makers need to take the socio-economic situation of the community of gatherers into account, changing the focus from the resource as such to the binomial gatherer-resource (Nordi 1994a; Alves and Nishida 2004; Alves et al. 2005), and look into alternative sources of income during the closed season.

\section{ACKNOWLEDGEMENTS}

We thanked FUNCAP (Fundação Cearense de Apoio ao Desenvolvimento Científico e Tecnológico - Grant BMD-0281-2.05/08) for providing a master grant to J.C.S. Linhares. To Programa de Pós Graduação em Ecologia e Recursos Naturais of UFC for support, to Allan Shellenk de Abreu Torres for the collaboration during the course of this study and Jesper R. Sampaio for the revision of the text in English.

\section{REFERENCES}

Adiyodi RG. Reproduction and its Control. In: Bliss DE, Mantel LH, editors. The Biology of Crustacea. New York: Academic Press; 1985. p. 147-215.

Alves RRN, Nishida AK. A ecdise do caranguejo-uçá, Ucides cordatus (Crustacea, Decapoda, Brachyura) na visão dos caranguejeiros. Interciencia. 2002; 27: 110117.

Alves RRN, Nishida AK. Aspectos socioeconômicos e percepção ambiental dos catadores de caranguejo-uçá Ucides cordatus cordatus (L.1763) (Decapoda, Brachyura) do Estuário do Rio Mamanguape, Nordeste do Brasil. Interciencia. 2003; 28: 36-43.
Alves RRN, Nishida AK. Population Structure of the Mangrove Crab Ucides cordatus (Crustacea: Decapoda; Brachyura) in the Estuary of the Mamanguape River, Northeast Brazil. Trop. Oceanog. 2004; 32: 23-37.

Alves RRN, Nishida AK, Hernandez MIM. Environmental Perception of Gatherers of the Crab Caranguejo-uçá (Ucides cordatus, Decapoda, Brachyura) Affecting Their Collection Attitudes. J. Ethnobio. Ethnomed. 2005; 1: 1-8.

Boeger WA, Pie MR, Vicente VA, Ostrensky A, Hungria DB, Castilho GG. Histopathology of the mangrove land crab, Ucides cordatus (Ocypodidae), affected by Lethargic Crab Disease: clues to understand the disease. Dis. Aquat. Org. 2007; 78: 73-81.

Bouchard S, Sainte-Marie B, McNeil JN. Indirect evidence indicates female semiochemicals release male precopulatory behaviour in the snow crab, Chionoecetes opilio (Brachyura: Majidae). Chemoecol. 1996; 7: 9-44.

Charniaux-Cotton H, Payen G, Ginsburger-Vogel T. Arthropoda-Crustacea: Sexual Differentiation. In: Adiyodi KG, Adiyodi RG, editors. Reproductive Biology of Invertebrates V. New Delhi: Oxford and IBH Publishing Co.; 1992. p. 281-323.

Christoffersen ML. Phylogenetic systematica of Eucarida (Crustacea Malacostraca). Rev. Bras. Zool. 1988; 5: 325351.

Costa RS. Biologia do caranguejo-uçá Ucides cordatus (Linnaeus, 1763) - Crustáceo, decápode - no nordeste brasileiro. Bol. Cear. Agron. 1979; 20: 1-74.

Diele K. Life history and population structure of the exploited mangrove crab U. cordatus (L.) (Decapoda: Brachyura) in the Caeté estuary, North Brazil $[\mathrm{PhD}$ Thesis]. Bremen, Germany: University of Bremen; 2000.

Diele K, Koch V. Growth and mortality of the exploited mangrove crab Ucides cordatus (Ucididae) in north Brazil. J. Exp. Mar. Biol. Ecol. 2010; 395: 171-180.

Diele K, Koch V, Saint-Paul U. Population structure, catch composition and CPUE of the artisanally harvested mangrove crab Ucides cordatus (Ocypodidae) in the Caeté estuary, North Brazil: Indications for overfishing? Aquat. Living. Resour. 2005; 18: 169-178.

Glaser M. Interrelations between mangrove ecosystems, local economy and social sustainability in the Caeté estuary, North Brazil. Wetl. Ecol. Manage. 2003; 11: 265-272.

Hartnoll RG. Mating in the Brachyura. Crustaceana. 1969; 16: 161-181.

Hartnoll RG. Growth, sexual maturity and reproductive output. In: Wenner AM, Balkema AA, editors. Factors in adult growth. Rotterdam: A.A. Balkema; 1985. p. 101-128.

Hartnoll RG, Broderick AC, Godley BJ, Saunders KE. Population structure of the land crab Johngarthia lagostoma on Ascension Island. J. Crus. Biol. 2009; 29: 57-61.

Hartnoll RG, Gould P. Brachyuran life history strategies and the optimization of egg production. Symp. Zool. Soc. Lond. 1988; 59: 1-9.

Ivo CTC, Gesteira TCV. Sinopse das observações sobre a bioecologia e pesca do caranguejo - uçá, Ucides 
cordatus cordatus (Linnaeus, 1763), capturado em estuários de sua área de ocorrência no Brasil. Bol. Téc. Cient. CEPENE. 1999; 7: 9-51.

Legat JFA, Puchnick AL, Castro PF, Pereira AML, Góes JM, Fernandes-Góes LC. Current fishery status of Ucides cordatus (Linnaeus, 1763) (Brachyura, Ocypodidae) in the Parnaíba delta region, Brazil. Nauplius. 2005; 13: 65-70.

Linhares JCS. Estratégias reprodutivas do caranguejo Ucides cordatus (Crustacea; Brachyura; Ucididae) [Master dissertation] Fortaleza, Brazil: Universidade Federal do Ceará; 2010.

Linhares JCS, Fernandes-Góes LC, Góes JM, Legat JFA. Perfil sócio-econômico e saber etnobiológico do catador de caranguejo-uçá, Ucides cordatus (Linnaeus, 1763) da Área de Proteção Ambiental do Delta do Rio Parnaíba. Sitien. Ser. Ciên. Biol. 2008; 8: 135-141.

Litulo C. Population structure and reproductive biology of the fiddler crab Uca inversa (Hoffman, 1874) (Brachyura: Ocypodidae). Acta Oecol. 2005a; 27: 135141.

Litulo C. Population biology of the fiddler crab Uca annulipes (Brachyura: Ocypodidae) in a tropical East African mangrove (Mozambique). Estuar. Coast. Shelf Sci. 2005b; 62: 283-290.

Melo GAS. Manual de Identificação dos Brachyura (Caranguejos e Siris) do Litoral Brasileiro. São Paulo: Plêiade/FAPESP; 1996.

Morgan SG. Influence of tidal variation on reproductive timing. J. Exp. Mar. Biol. Ecol. 1996; 206: 237-251.

Nascimento SA. Biologia do caranguejo-uçá (Ucides cordatus). Aracajú: ADEMA; 1993.

Nordhaus I, Diele K, Wolff M. Litter processing and population food intake of the mangrove crab Ucides cordatus in a high intertidal forest in northern Brazil. Estuar. Coast. Shelf Sci. 2006; 67: 239-250.

Nordi N. A captura do caranguejo-uçá (Ucides cordatus) durante o evento reprodutivo da espécie: o ponto de vista dos caranguejeiros. Rev. Nord. Biol. 1994a; 9: 4147.

Nordi N. A produção dos catadores de caranguejo-uçá (Ucides cordatus) na região de Várzea Nova, Paraíba, Brasil. Rev. Nord. Biol. 1994b; 9: 71-77.

Nordi N. O processo de comercialização caranguejo-uçá (Ucides cordatus) e seus reflexos nas atitudes de coleta. Rev. Nord. Biol. 1995; 10: 39-46.

Nordi N, Nishida AK, Alves RRN. Effectiveness of Two Gathering Techniques for Ucides cordatus in Northeast Brazil: Implications for the Sustainability of Mangrove Ecosystems. Hum. Ecol. 2009; 37: 121-127.

Pinheiro MAA, Fiscarelli AG. Manual de apoio à fiscalização do caranguejo-uçá (Ucides cordatus). Itajaí: CEPSUL; 2001.

Pinho MR, Gonçalves JM, Martins HR, Menezes GM. Some aspects of the biology of the deep-water crab, Chaceon affnis (Milne-Edwards and Bouvier, 1894) off the Azores. Fish. Resea. 2001; 51: 283-295.

Rodrigues AMT, Branco EJ, Saccardo SA, Blankensteyn A. A explotação do caranguejo Ucides cordatus (Decapoda: Ocypodidae) e o processo de gestão participativa para normatização da atividade na região sudeste-sul do Brasil. Bol. Inst. Pes. 2000; 26: 63-78.

Sainte-Marie B. Sperm demand and allocation in Decapod Crustaceans. In: Duffy JE, Thiel M, editors. Evolutionary Ecology of Social and Sexual Systems: Crustaceans as Model Organisms. New York: Oxford University Press; 2007. p. 191-210.

Sant'Ana R, Pezzuto PR. Sexual maturity of the deep-sea red crab Chaceon notialis Manning and Holthuis, 1989 (Brachyura: Geryonidae) in southern Brazil. Lat. Am. J. Aquat. Res. 2009; 37: 429-442.

Sastry AN. Ecological aspects of reproduction. In: Wenner A, Kuris A, editors. The Biology of Crustacea, VIII Environmental adaptations. New York: Academic Press; 1983. p. 179-270.

Schories D, Barletta-Bergan A, Barletta M, Krumme U, Mehlig U, Rademaker V. The keystone role of leafremoving crabs in mangrove forests of North Brazil. Wetl. Ecol. Manage. 2003; 11: 243-255.

Silva JRF, Gesteira TCV, Rocha CAR. Relações morfométricas ligadas à reprodução da lagosta espinhosa, Panulirus laevicauda (Latreille) (Crustacea: Decapoda: Palinuridae) do estado do Ceará - Brasil. Bol. Técn. Cient. CEPENE. 1994; 2: 59-88.

Souto FJB. Uma abordagem etnoecológica da pesca do caranguejo, Ucides cordatus, Linnaeus, 1763 (Decapoda: Brachyura), no manguezal do Distrito de Acupe (Santo Amaro-BA). Biotemas. 2007; 20: 69-80.

Stearns SC. The evolution of live histories. New York: Oxford University Press; 1992

Wolff M, Koch V, Isaac V. A trophic flow model of the Caeté mangrove estuary (North Brazil) with considerations for the sustainable use of its resources. Estuar. Coast. Shelf Sci. 2000; 50: 789-803.

Wunderlich AC, Pinheiro MAA, Rodrigues AMT. Biologia do caranguejo-uçá, Ucides cordatus (Crustacea: Decapoda: Brachyura), na Baía da Babitonga, Santa Catarina, Brasil. Rev. Bras. Biol. 2008; 25: 188-198.

Varpe O. Life history adaptations to seasonality $[\mathrm{PhD}$ Thesis]. Bergen, Norway: University of Bergen; 2006.

Vasconcelos EM, Vasconcelos JA, Ivo CT. Estudo sobre a biologia do caranguejo-uçá, Ucides cordatus (Linnaeus, 1763) capturado no estuário do rio Curimatau (Canguaretama) no Estado do Rio Grande do Norte. Bol. Téc. Cient. CEPENE. 1999; 7: 53-84.

Vasconcelos JLA. Biologia do caranguejo-uçá e perfis sócio-econômico e etnobiológico dos coletores em duas áreas de manguezais em Ilhéus-BA [Master dissertation]. Ilhéus, Bahia: Universidade Estadual de Santa Cruz; 2008.

Xiao Y, Kumar M. Sex ratio, and probability of sexual maturity of females at size, of the blue swimmer crab, Portunus pelagicus Linneaus, off southern Australia. Fish. Resea. 2004; 68: 271-282.

Received: May 09, 2011; Revised: September 27, 2011; Accepted: May 07, 2012. 